\title{
Multidisciplinary approach for curriculum design of professional master's program with focusing on solidary economy in Oaxaca, Mex
}

\author{
Rasilla Cano Margarita and Juárez Ruiz Lidia Argelia* \\ Instituto Politécnico Nacional CIIDIR Oaxaca. Hornos 1003, Colonia Nochebuena, Santa Cruz Xoxocotlán, Oax. \\ 71230, Mexico.
}

Received 26 January, 2016; Accepted 7 June, 2016

\begin{abstract}
The IPN Oaxaca CIIDIR has a mission to train human resources to postgraduate level that contribute to sustainable regional development in the South-East of Mexico. This is a vulnerable region that boasts an important source of natural resources and a great social, economic and technological backwardness that is directly related to the educational aspect. A master's degree has been designed with three lines of work, taking into account the strengths of the CIIDIR-Oaxaca: Design and sustainable technologies to the building, Security and food safety, and water resources. The aim is to encourage the transfer of knowledge and technology, with methodologies that allow promoting the work of collaborative multi and interdisciplinary and linking with the professional sector. The curriculum design responds to the educational model of the IPN, this model is characterized as facilitator of professional skills and too responds to the model of social integration. The curriculum of the master degree in "Project management for the solidary development" was designed with vocational guidance in response to the shortcomings detected in the region about social and environmental problems, through relevant diagnosis and analysis. This program is included in the PNPC-CONACYT'. The starting point of this methodology is the social order and the context deals with the social, economic and environmental aspects. The training of graduate students has the focus of solidarity economy and sustainability as an alternative view and feature in the proposal of projects to manage.
\end{abstract}

Key words: Curriculum, graduate, sustainability, management and development in solidarity.

\section{INTRODUCTION}

The social, environmental and economic problems, on the State of Oaxaca in particular and the south-southeast Mexican region in general, present similarities that turn it into a socially, economically and environmentally vulnerable region. This region has an important source of natural resources and at the same time a great social, economic and technological backwardness directly related with the educational aspect.

The society is a system in which all sectors have interconnections at different levels, and therefore respond

*Corresponding author. E-mail:lidiargelia@gmail.com.

Authors agree that this article remain permanently open access under the terms of the Creative Commons Attribution License 4.0 International License 
to a dynamic that generates new challenges on an ongoing basis, and the educational institutions must plan based on this dynamic, in order to give sense to its fundamental actions, develop human talent, generate knowledge for the resolution of social problems with a multidisciplinary approach. This becomes one of the challenges of education for the knowledge society (Tobón, 2013).

As a response to this context, for over 30 years and trough the CIIDIR ${ }^{1}$ Oaxaca, the IPN ${ }^{2}$ intends to form postgraduate level human resources that contribute to sustainable regional development (CIIDIR, 2012a). Considering this as a starting point and with the purpose to promote the development of the South-Southeast region of Mexico, we design the master in "Project management to solidary development" with professional profile. Its vision is to generate actions solution to unemployment as a response to the identified needs of the region. This postgraduate course is the result of a curriculum design that encourages the inclusion of curriculum actors (managers and teachers), and supported collaborative work with a teacher training process, resulting in a curriculum that is flexible, multidisciplinary and enabler of professional competences.

According to Tobon (2013), it is necessary to transform the current education that transcends the emphasis in content and begin to focus on the resolution of context problems. Here is described, in a general way, the process that led to open the first generation of the master degree in August 2013, and determine the main objective, to train professionals at postgraduate level with skills in solidary self-management, collaborative work, practices of participatory democracy and ethical values, in order to identify, implement and evaluate projects in three strategic areas: Food Safety And Food Security, Water Resources and, Design and Sustainable Technologies for the Building, under the solidary economy approach, in urban and rural communities. As a result of this methodology, the master's degree with professional orientation in "Project Management for solidary development", managed to be included in the quality postgraduate register of the CONACYT (PNPC) in October 2013. This action involves, among others, the transformation of researchers CIIDIR-IPN into a teaching practice where the appropriation of the curriculum is given from participation in multidisciplinary design expertise.

\section{APPROACH AND METHODOLOGY}

The institutional tradition of design plans and curricula, is being replaced by an instrument of organization and academic articulation, in which framework, dynamic, flexible and integrated

\footnotetext{
${ }^{1}$ CIIDIR. Interdisciplinary Research Centre for the Regional Integral Development

${ }^{2}$ IPN. National Polytechnic Institute
}

manner, it is expressed and the Educational Model of IPN (2004a) projects characterized as facilitator of professional skills. This instrument must also respond to the Social Integration Model (IPN, 2004b), his concept of research and its organizational structure. This instrument is the Curriculum. In the IPN have not reported the design of a professional master from this perspective and regional level either, so it can be said that the CIIDIR IPN Oaxaca is a pioneer in the use of systemic methodology to graduate level curriculum. Also this postgraduate program has been incorporated into standard quality graduate CONACYT, practically since its inception.

In many cases the curriculum theories set guidelines that are impossible to follow completely so it is necessary to incorporate concepts and procedures appropriate for the context of implementation. A curriculum design that responds only to a single theoretical position, leads to tensions between formal or established curriculum from the hidden or real position (Rangel, 2015). This work shows the result of collaborative work, slow and tense, and can be described as democratic, from its design and also in its implementation, unique in the IPN.

If one of the indicators of relevance of the curriculum begins at conception design based on the context to which there is impact, for this design, more contextual elements of rural and urban reality can be said to be included during processing that bureaucratic elements. This allowed generation of an inclusive system of several social actors with a multidisciplinary vision (Coll, 1990).

According to Stenhouse (1975), integrating needs contextual and focused on learning, this design is flexible, open to the needs of the learner. The (intentional) contents should be adapted to the individual projects of each student, in such a way that they cater to the functionality of the learning (Taylor, 1991).

The starting point of this methodology is the social commitment, understood as the requirements established by the society to educational institutions. These requirements are relative to the solution capacity of the current and perspective problems on the part of the professional graduates from these institutions, and by its academic staff and managers. For this reason it is considered that the curriculum design should be develop by the executors of the same, that is, the academic group and management, defining the context in which it will be implemented. In this master's program, the context addresses the social, economic and environmental aspects and training the graduate has the focus solidarity economy and sustainability, as an alternative vision and feature in the proposed projects to manage.

The organization of the faculty of teachers who are involved in curriculum design, characterized as a multidisciplinary group, responded to the various stages of design, which always involved the formation of the working group through participatory techniques, to perform various tasks such as Analysis of the problems and social custom, detection of strengths and weaknesses of the educational institution, training for curriculum design assisted, determination of competencies required in the postgraduate program, approach determination of the postgraduate program, general curriculum design: determination of the graduation profile and the entry profile, formation of work lines and the curricular map, strengths and weaknesses detection of the academic group and, Strategies for implementation and launch of the postgraduate course.

Once the social problem has been identified and defined, and since the process does not end only with the design, we proceed to establish a general plan that allows having quality elements, because we must operate it, evaluate it and compare it with the problem at a later moment, which surely, it will require of a redesign according to the context characteristics at the time. Always taking into account, this initial design will evolve as long as we are aware of the permanent need of evaluation. The described process responds to a Program of continuous improvement that goes with the curriculum design. 


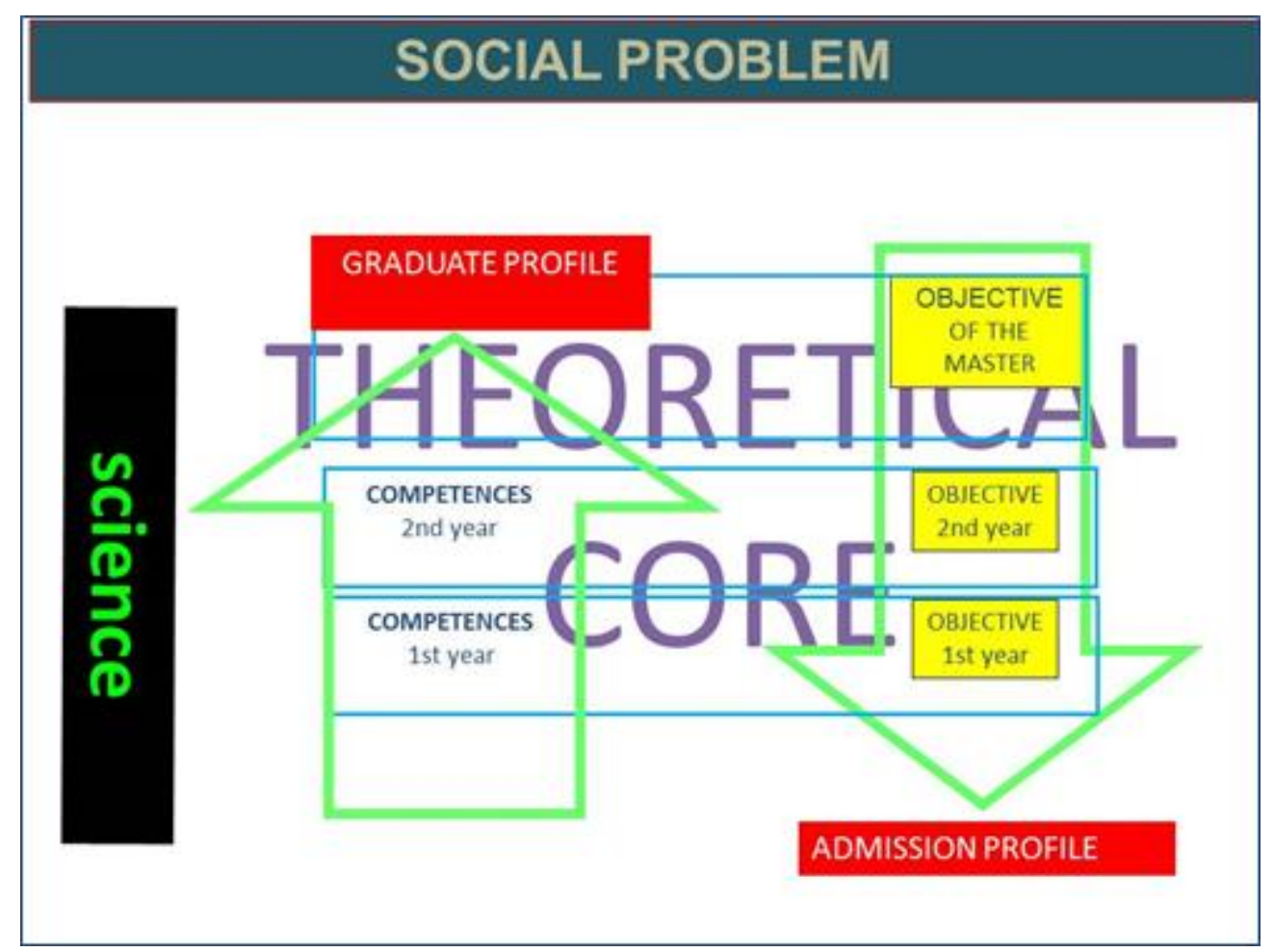

Figure 1. Foundations of curriculum design competence from the social problem. (Rasilla, 2007)

With the above set is necessary to redact the educational objective, keeping in mind the Level of competence that allows us to propose solutions to real problems, in other words, the answers to next questions must be explicit. The professional to be educated: What does he solves? What doesn't he solve? and what does he participate?

The objective allows visualizing and defining the competences that will be contributed to during the educational process, defining the graduation profile, which must be frame, in a natural way, with the social problem and the objective. By integrating a concept that allows us to give identity and technical-scientific support to the curriculum, appears the theoretical nucleus. From this moment on, it is necessary to determine which sciences will contribute with its contents to achieve this profile.

The derivation of targets for the levels prior to the general objective and its corresponding level profile (Figure 1), provides a matrix as a guide for tactical assessment process. Since each object is checked in accordance with the knowledge acquired at each level. The input profile (CIIDIR, 2012b) is defined as a logical consequence of this analysis.

The competences in the second year, does not necessarily have to match their level, the profile exit, because surely a process of closing the productive project will be necessary and / or social; and of course the defense of the master's thesis, which complements the learning process of students. With this overview, we begin with the curriculum design, and later the study program. This program is based on the conceptual, procedural and value contents in order to integrate the competencies (Figure 2). The general and specific competences were determined by the work groups for each line.

\section{DESIGN DEVELOPMENT}

In the CIIDIR Oaxaca were invited a total of 23 teachers to integrate a multidisciplinary group, in February 2011. Group that was finally reduced to 15 members who completed the general design of the curriculum 15 months later.

The design began justifying the problematic elements that supported the need for graduate level educational offer directed towards a professional profile. As an initial task, the group became involved in the definition of the social problem that will affect graduates of this expertise, based on the regional context, the Mission, Vision and strengths of the CIIDIR-IPN Oaxaca Unit and guiding principles institutional (IPN, 2004c).

One of the specific objectives of this first plan is to unite the developer group, based on the discussion of the scope of this work, its strengths and limitations. Allowing to establish a viable, real and achievable objective, which permanently will need to resort to the self-assessment. In the case of the master's we were able to determine, through consensus of interdisciplinary groups, the following (CIIDIR, 2012b):

"At the heart of the grave socio-economic and environmental situation of the state of Oaxaca, we have begun to develop some productive transformations, some of which today have international recognition for the type of local progress they generate, such is the case of Community-based Forest Enterprises, organic Production of coffee, honey, among others. These productive partnerships operate under an organization scheme according to traditions and customs. They are linked with ONG universities and research centers, so they can generate specific knowledge that helps them get a better economic, social and environmental development. The promotion to this type of initiatives constitutes the mission of the Master's degree in Project Management for Solidary Development. Train professionals who are able to identify and cooperate on the construction of viable productive projects economically, environmentally and socially. Projects meant to increase the people's life quality trough solidary and sustainable organization. We will train professionals capable to make incursions into 


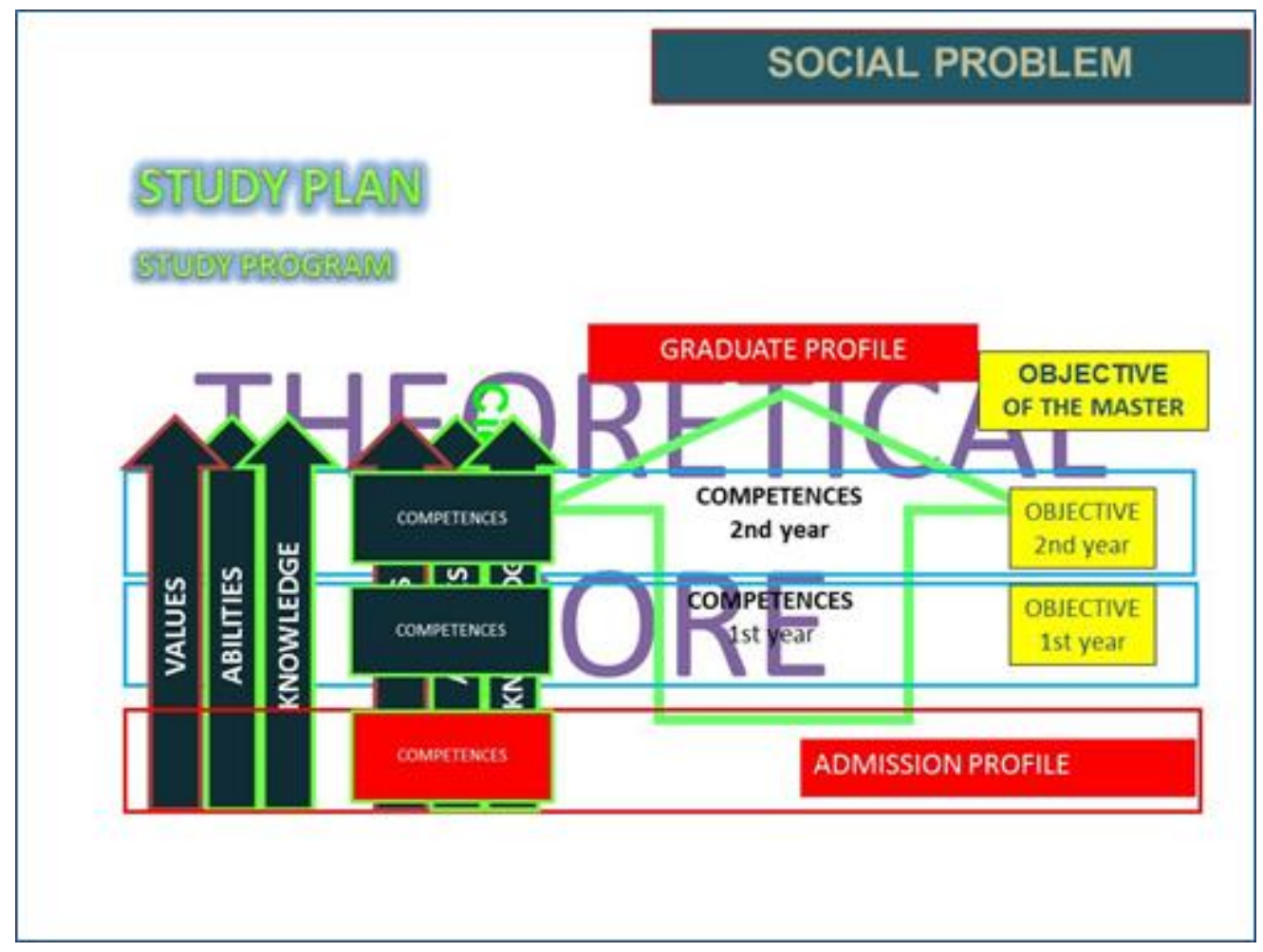

Figure 2. Scheme of the integration of the curriculum from competences. (Rasilla, 2010).

management of sustainable regional projects, under the approach of solidary economy in the areas of food security and food safety, design and sustainable technologies for the building, and water resources. With the perspective of opening their own working field through project managing, consults and/or inclusion in specific areas of public and private institutions, from an integral and interdisciplinary perspective, to increase the communities life quality. The master will contribute not only to the objective of Solidary and Sustainable Development of Oaxaca, but also of the country southeast region that presents similar indicators to those of this state".

At this point in the design, we write the formative objective taking into account the competence level that allows proposing solutions to real problems. During this design working groups were organized by committees for each one of the different stages, and also existed disciplinary work as a transversal work. Achieving the following results (CIIDIR, 2012b):

"Master's degree objective: Train professional to postgraduate level with competences solidary self-management, collaborative work, practices of participatory democracy and ethical values to identify, apply and evaluate projects in three strategic areas: Food Safety and Food Security, Water Resources and Design and Sustainable Technologies for the Building, under the approach of Solidary Economy in urban and rural communities".

The social problem being addressed leads to the definition of the three lines of work to achieve the objective of the master, so the exit profile diversifies depending on the line that the student chooses to guide your project, without losing sight interdisciplinary (CIIDIR, 2012b):

"Entry profile: The applicant must be a professional committed with the search of alternatives to social, economic and environmental problems, being critic and reflexive. Moreover he must have a professional degree in an area of knowledge that has affinity with any of the following lines of work and terminal options, offer by the Master's degree project management for solidary development.

1.Food safety and food security: Generate productive projects is what it's intend here, projects that improve the productive process, include basic growing and local resources for the local populations nutrition, and generate mechanisms of technology transfer to create value added, just as the acknowledgement and creation of solidary associative networks. Aimed at graduates from agronomy, agro ecology, biotechnology, biochemistry, nutrition and similar careers. 2. Water resources: The objective of this line is to strengthen the education of professionals that promote a change on the current conception of water management, based on the approach of integral management of water and solidary development. Aimed at graduates from civil, industrial, chemical and environmental engineers, hydrology, geology, biological sciences.

3. Design and sustainable technologies for the build: On this line, in order to improve the habitability of housing and buildings in general, design aspects will be considered, that provide security, comfort, illumination, ventilation, orientation, just as the materials characteristics and the construction place conditions. Aimed at graduates from civil engineer, environmental engineer, architecture and similar careers.

Furthermore, to enter the program, the next basic competences are required:

(i) Reading and comprehension of English texts.

(ii) Skill for documental and field investigation.

(iii) Software knowledge to create and work with texts, graphics and 
spreadsheets.

(iv) Interest and disposition to deal with problems of their environment, related with their discipline with a focus on sustainability.

(v) Disposition for self-learning.

(vi) Innovative spirit.

(vii) Disposition for multidisciplinary work and team work.

Graduate profile: Graduate in project management for solidary development. Identify, to design, manage and evaluate projects based on the conceptual fundaments of solidary economy. He will dispose of a combination of theoretical methodological knowledge, skills and values that will allow him to have high performance when applying with a suitable and practical way, the acquired knowledge in design and sustainable technologies for the building, food safety and food security, and water resources.

In addition, students will acquired transformation competences and skills for self-employment and facilitate his access to sources of employment in areas related to sustainability. The competence for transformation describe the ability of future vision, that is required to structure the approach to sustainability and solidary economy through the active participation in the future of the society. That is why we include in this profile the next sub competences of transformation (Michelsen and Rieckamnn, 2008)

(i) Competence for thinking ahead (prospective) that allows him to work with uncertainties, as well with predictions, expectations and future concepts.

(ii) Competence for working in an interdisciplinary manner.

(ii) The competence for a wide perception that allow the intercultural understanding of communication and cooperation.

(iv) Competence for critic reflection of paradigms.

(v) Being able to plan, supervise and execute projects, identify niches of opportunity, adapt technological innovations, apply technologies.

(vi) Having an attitude of commitment, respect, and responsibility, highlighting the professional ethics with the social and ecological environment.

(v) Promoting the understanding of the sustainability value.

(vi) Coping with climate change and energy-related needs. "From the definition of these parameters, we proceeded to the design of the curriculum, and then, the study program of the common part and the three work lines. The design is based on the conceptual, procedural and content values, to integrate the relevant competence. The institutional regulation of the IPN establishes the integration of learning units as training cells that integrate the curriculum.

The Master's program "project management for the solidary development" was included in the National Register's Quality Postgraduates (PNPC) CONACYT of Mexico in October 2013.

\section{RESULTS}

The academic group of the Interdisciplinary Center of Research for the Regional Integral Development, Oaxaca Unit of the IPN, and based on this work methodology, established the next curriculum map (Figure 3).

Definitions of the work lines was based on the needs detected in the diagnostic of the regional context and on the skills developed during the 30 years of CIIDIR operating in the State of Oaxaca. In the same way we detected that the lines of economy, education and energy, are necessary, and due to lack of strength of academic staff in the CIIDIR Oaxaca to work with them as lines, currently only included in a transversal way.

The Master's modality is formal and classroom education, with intra and extramural activities, with prevalence of linked and articulated activities by the school activities. This activities outline in the learning Units, are mandatory in the common part and project seminars, and optional the corresponding to the work lines according to the project to develop.

This curriculum design considers the learning units of the common or basic stock, as the responsible for developing skills and values that must permeate in the planning, design, ex-ante evaluation and implementation of projects supported on the theoretical-conceptual elements. The project Seminars are considered the curriculum integrative spaces, since its aim is the permanent assessment of learning, teaching, relevance of the contents and the feasibility of operation (educational management), trough 1) identify an economic, social and environmentally viable project (Protocol integration); 2) design the project; 3) make an ex-ante evaluation of economic, social and environmental variables for its implementation and 4) implement the project in field and the ex-post evaluation.

\section{DISCUSSION}

According to Tobon (2013b), the implementation of the curriculum is important based on competencies, in accordance with current social challenges and trends towards the future, the quality management of learning and the training of people with critical thinking, entrepreneurship and ethical performance that are basics aspects of this design curriculum.

The master's program opened its first semester on August 2013, currently has 22 students, and 3 graduates; the applicants were selected through an admission process focused on the evaluation of general and specific competences, through the application of institutional instruments and instruments design by the academic group that is responsible for the operation of the master. The process consisted in a series of interviews conducted by a member of each work line, common group and projects seminars, just as the presentation and defense of a first draft of interest for the applicant, according to his entry profile and demonstrating the inclusion of the solidary development vision.

As a result of self-assessment and the process of continuous improvement, we will offer new optional learning units to strengthen the training for the management of projects (elements for multidisciplinary teaching and environmental management). In addition to this, the permanent seminar on strengthening the multidisciplinary training of students has started, that involves specific actions on the needs identified in the curriculum learning units and that are attended by external experts strengthening the linkage with the real 


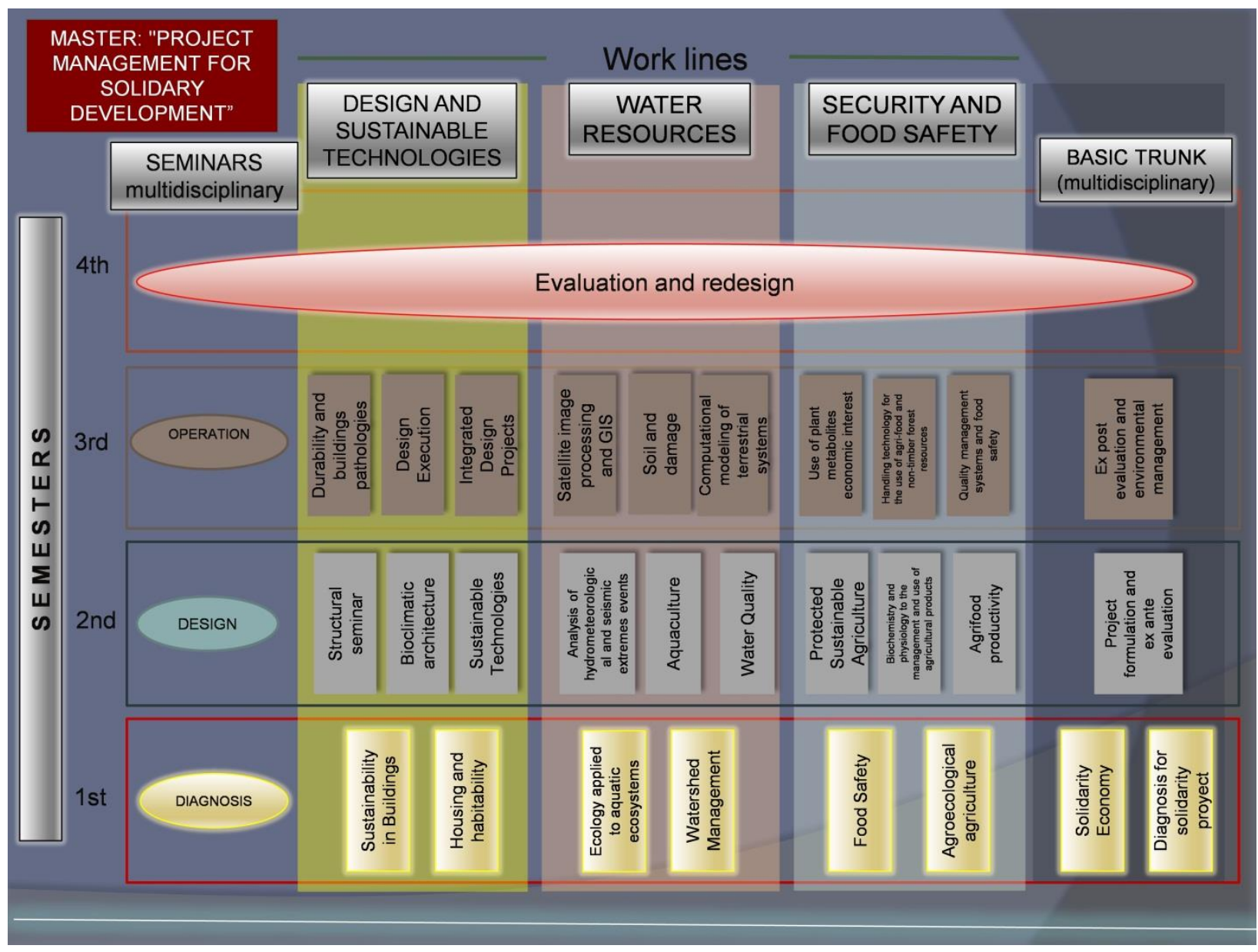

Figure 3. Curriculum map. Master's degree in "Project Management for the solidary development" IPN. CIIDIR (2012b).

problems of the region. These specific actions are conferences, round table discussions and visits to specific communities to address any issue or a social program evaluation. The latter are independent of the field visits planned in some of the learning units.

\section{CONCLUSIONS}

From this methodology, it was detected that it is possible to diversify the graduation profile. Solving the problem, using the Center resources and institutional strength, enabled the problem to be addressed from three disciplinary areas.

(i) The integration of disciplinary groups and committees allowed the definition of disciplinary and generic competences that needed to be promoted, besides finding matches in competences by disciplinary areas to the called nodal specific competences. This methodology of curriculum design promotes the inclusion of the curriculum creators (Managers and teachers) and the collaborative work of teachers, resulting in a curriculum that is flexible, interdisciplinary and enabler of professional competences.

(ii) The permanent teacher training, during the process of curriculum design, allowed a construction of learning in teachers that respond to the needs that arose them. The integration of multidisciplinary groups allowed the design methodology to be enriched. The curriculum design process, and the design and operation of the admission process, has given us elements to make a pre-evaluation of the relevance of the master's and its procedures, since the operation of the first semester.

(iii) The graduation profile of the master's allows the students to apply their knowledge for self-employment, through the generation and application of solidarity projects and/or technical consultancies, and the managing the necessary resources for the implementation. This process of curriculum design has involved a vision of systemic nature, flexible, of permanent evaluation (internal, external and meta-evaluation) with a learning vision, inclusive and with a view of contributing to the solution of real problems of one of the three poorest 
states and with the greater diversity of the country.

With this systemic process, flexible and with a vision of continuous improvement to ensure its relevance, we strive to bring about changes in the training of high-level professionals. According to Tobon (2013), it is expected that the majority of students are going to have a wellrounded education and they are going to be able to respond to the challenges of today and in the future.

\section{Conflict of interests}

The authors have not declared any conflict of interests.

\section{ACKNOWLEDGEMENTS}

To the National Polytechnic Institute - IPN, CONACYT. The working group who participated in the curriculum design of the master in "Project management for the solidary development".

\section{REFERENCES}

Coll C (1990). Psicología y currículum, Una aproximación psicopedagógica a la elaboración del currículum escolar. México: Paidós.

IPN (2004a). Nuevo Modelo Educativo para el IPN, Materiales para la Reforma No. 1. México, IPN.

IPN (2004b). Modelo de Integración Social del IPN, Materiales para la Reforma No. 4. México, IPN.

IPN (2004c). Manual para el rediseño de planes y programa de estudio en el Marco del modelo educativo y académico. Materiales para la Reforma No. 12. México, IPN.

CIIDIR (2012a). www.ciidiroaxaca.ipn.mx, consultado 22 septiembre 2014. Provide title of work.

CIIDIR (2012b). Diseño curricular de la maestría con orientación profesional: Gestión de proyectos para el desarrollo solidario. CIIDIR Oaxaca, IPN

Michelsen G, Rieckmann M (2008). "Programa de Maestría Internacional: Sustainable Development and Management". Alemania: Verlag für Akademische Schriften.

Rangel H (2015). Una mirada internacional de la construcción curricular. Por un currículo vivo, democrático y deliverativo. Revista Electrónica de Investigación Educativa 17(1):1-16.
Rasilla Hernández, Baltazar (2007). "El curriculum y la calidad en la educación". En memorias del ier congreso internacional de educación media superior y superior para la juventud del futuro. ciudad de méxico. gobierno de la ciudad de méxico.

Rasilla, Hernández, Baltazar (2010). Metodología de diseño integral del curriculum. En memorias del II Foro De Profesores "Diseño curricular. Ciudad de México. ESIQIE-IPN.

Stenhouse L (1975). An introduction of curriculum research and development. Londres: Heineman.

Taylor C (1991). El multiculturalismo y la política del reconocimiento. México: Fondo de Cultura Económica

Tobón S (2013). Los Proyectos Formativos: Transversalidad y desarrollo de competencias para la sociedad del conocimiento. México D.F. Instituto CIFE

Tobón S. (2013b). Metodología de gestión curricular. Una perspectiva socioformativa. México. Trillas.

\footnotetext{
${ }^{i}$ National Quality Postgraduate Program of National Council of Science and Technology in Mexico.
} 